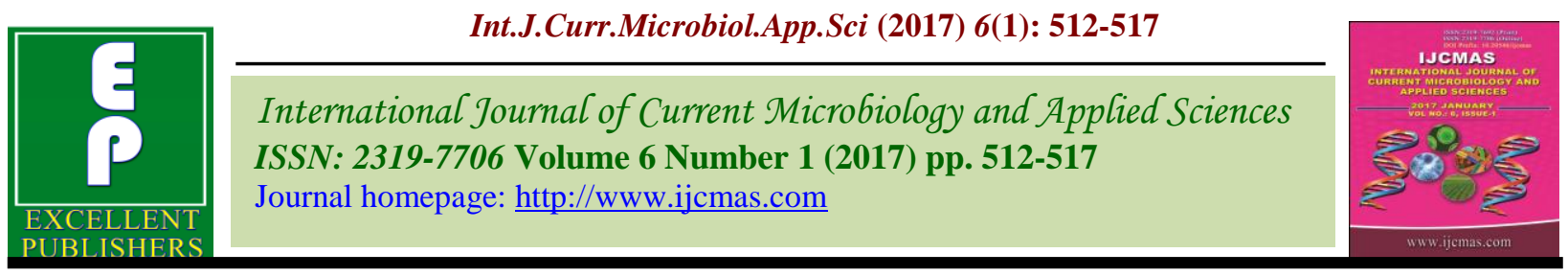

Original Research Article

http://dx.doi.org/10.20546/ijcmas.2017.601.061

\title{
Antibacterial Activity of Soap containing Hexane Extract of Leaves of Morinda morindoides (Morinda; Rubiaceae) against Staphylococcus aureus and Pseudomonas aeruginosa
}

\author{
Toure Abdoulaye ${ }^{1,2} *$, Konan Kouakou Severin ${ }^{1,2}$, Coulibaly Bakary ${ }^{2,3}$, \\ Ouattara Karamoko ${ }^{2}$ and Coulibaly Adama ${ }^{2}$
}
${ }^{1}$ Laboratoire de Biotechnologie et Valorisation des Agroressources-UFR Sciences Biologiques, Université Peleforo GON COULIBALY à Korhogo, 1328 Korhogo, Côte d'Ivoire.
${ }^{2}$ Laboratoire de Pharmacodynamie Biochimique-UFR Biosciences, Université Félix
HOUPHOUET BOIGNY à Cocody-Abidjan, 22 BP 582, Abidjan 22, Côte d'Ivoire
${ }^{3}$ Département de Biochimie-Microbiologie-UFR Agroforesterie, Université Jean LOROUGNON
GUEDE à Daloa, BP 150 Daloa, Côte d'Ivoire.
*Corresponding author

A B S T R A C T

Keywords

Morinda morindoides, hexane extract, soap, antibacterial activity, Côte d'Ivoire.

Article Info

Accepted:

23 December 2016

Available Online:

10 January 2017
The objective of this study was to perform antibacterial activity of soap containing hexane extract of leaves of Morinda morindoides (Baker) Milne-Redh (Rubiaceae) codified "MORINDA" against Staphylococcus aureus and Pseudomonas aeruginosa. This soap was developed by incorporation hexane extract of $M$. morindoides as antimicrobial agent in formula of basic soap (soap without extract). Minimum inhibitory and bactericidal concentrations (MIC and MBC) of soap "MORINDA" and basic soap against the two above bacteria strains were determined by agar both dilution and plate methods. The results showed high bactericidal activity of soap "MORINDA" against two strains tested with same values of MIC and MBC of $31.25 \mathrm{mg} / \mathrm{mL}$. Basic soap presented the lower bactericidal effect with MIC of $62.50 \mathrm{mg} / \mathrm{mL}$ for the two strains tested and MBC of 125.00 $\mathrm{mg} / \mathrm{mL}$ and $62.50 \mathrm{mg} / \mathrm{mL}$ respectively for $S$. aureus and $P$. aeruginosa. Comparatively to control soap, hexane extract of $M$. morindoides gave to soap "MORINDA" effectiveness bactericidal power against these two bacteria involved in cutaneous infections. This study corroborate our previous investigations which showed antifungal activity of this soap and high antibacterial activity of hexane extract of $M$. morindoides.

\section{Introduction}

Multiple drug resistance in human pathogenic microorganisms has been developed due to indiscriminate use of commercial antimicrobial drugs commonly used in the treatment of infectious diseases. The development of antibiotic resistance is multifactorial, including the specific nature of the relationship of bacteria to antibiotics, the usage of antibacterial agent, host characteristics and environmental factors (Langlois-Klassen et al., 2007; Patwardhan et al., 2005). This situation has forced scientists to search for new antimicrobial substances from various sources as novel antimicrobial chemotherapeutic agents, but the cost production of synthetic drugs is high and they 
produce adverse effects compared to plant derived drugs (Abiramasundari et al., 2011; Parrales et al., 2012). These antimicrobial substances are of natural origin, and it is thought that their influences on the environment are few and can be used as biological control agents (Abdel Rahman et al., 2011). In this perspective Morinda morindoides has been subject of several research studies. This plant is well known in traditional medicine in Côte d'Ivoire and Democratic Republic of Congo for treatment of diarrhea and some parasitic diseases (Zirihi et al., 2005; Cimanga et al., 2006). The decoction of leaves of $M$. morindoides is used for treatment of malaria and amoebiasis (Kambu et al., 1990). Also different extracts (aqueous, ethanol, ethyl acetate, hexane) of leaves of plant are showed some interesting biologicals activities (Zihiri et al., 2005; Bagre et al.,2007; Moroh et al., 2008; Meite et al., 2009; Cimanga et al., 2010). In previous study, hexane extract of leaves of this plant revealed in vitro bactericidal properties against Staphylococcus aureus and Pseudomonas aeruginosa (Ouattara et al., 2013). In addition, this extract incorporated in formula of basic soap presents interesting antifungal activity (Toure et al., 2010). The purpose of this study consist to evaluated in vitro antibacterial activity of this soap against $S$. aureus and $P$. aeruginosa, two bacteria implicated in some cutaneous infections.

\section{Materials and Methods}

\section{Collection of Plant material}

Leaves of $M$. morindoides (Rubiaceae) were collected from Daloa (central west region of Ivory Coast). The plant was identified and authenticated with voucher specimen no. 17710 in herbarium of National Floristique Center of University Felix Houphouët Boigny (Côte d'Ivoire).

\section{Preparation of extract}

Leaves of $M$. morindoides were cleaned of extraneous matter, air-dried at room temperature for 7 days and ground into a fine powder. For each extraction, $100 \mathrm{~g}$ of dry powdered plant material was extracted with $250 \mathrm{ml}$ of hexane (Merck, Darmstadt, Germany) for $24 \mathrm{~h}$ using a Soxhlet extractor. Extract was filtered with Whatman filter paper no.1, and filtrate was evaporated under vacuum in a rotary evaporator (Buchi) at $55^{\circ} \mathrm{C}$. A greenish paste obtained with a yield of $9.24 \pm 0.18 \%$ is hexane extract.

\section{Preparation of soap}

The soap codified "MORINDA" was obtained with the cold method by adding 2 mixtures $A$ and B. Mixture A was obtained by dissolving $16.135 \mathrm{~g}$ of sodium hydroxide crystals in $59.58 \mathrm{~g}$ of distilled water. To sodium hydroxide solution obtained after 24 hours were added $1.5 \mathrm{~g}$ of sodium chloride and $1.2 \mathrm{~g}$ of sodium bicarbonate at the time of use. The mixture B which will be used as fat in preparation of soap consists of $50 \mathrm{~g}$ of coconut oil and $50 \mathrm{~g}$ of palm oil. Mixture A was gradually added with stirring to mixture B. The mixture $(\mathrm{A}+\mathrm{B})$ obtained was homogenized until a viscous mass (tracing) was formed. To obtain soap "MORINDA", 10 $\mathrm{g}$ of hexane extract of M. morindoides was added to $90 \mathrm{~g}$ of soap mass obtained (basic soap) and then homogenized. Homogeneous mass obtained was poured into the molds. In parallel, control soap was prepared according to same method but without hexane extract (basic soap). After 24 hours, two types of soaps are obtained: A soap with greenishcolored containing hexane extract of $M$. morindoides which is the soap "MORINDA" and a soap with no extract of $M$. morindoides which is basic soap (Caubergs, 2008; Oladele et al., 2010). 


\section{Bacterial strains}

The bacteria used in this study were Staphylococcus aureus (587/10) and Pseudomonas aeruginosa (602/10). These hospital strains were all identified following NCCLS recommendations by Bacteriological Laboratory of Pasteur Institute of Côte d'Ivoire.

\section{Antibacterial assay}

Antibacterial activity of soap containing hexane extract of $M$. morindoides (soap "MORINDA") and soap without extract (basic soap) against $S$. aureus and $P$. aeruginosa were performed by Mueller Hinton growth medium with broth dilution agar method coupled and seeding on agar plate. Each test soap was incorporated into growth medium in tubes and Petri dishes to give serial two fold dilutions. The resulting concentrations ranged from 1.95 to 125 $\mathrm{mg} / \mathrm{ml}$. A tube and Petri dishe containing nutrient broth only, seeded with test organism was served as growth control. Bacterial cell suspensions were inoculated on the tubes and plates using a bacterial planter $(0.3 \mathrm{ml}$ for $S$. aureus and $0.1 \mathrm{ml}$ for $P$. aeruginosa). All the inoculated tubes and plates were then incubated at $37^{\circ} \mathrm{C} \pm 2^{\circ} \mathrm{C}$ for $18 \mathrm{~h}$. The lowest concentration of the plate, which did not show any visible growth after incubation, was considered as minimal inhibitory concentration (MIC). To determine the minimal bactericidal concentration (MBC) for each set of test tubes in the MIC determination, a loopful of broth was collected from those tubes which did not show any growth and inoculated on sterile nutrient agar by streaking. Plates inoculated with bacteria were then incubated at $37^{\circ} \mathrm{C}$ for 24 hours. After incubation the concentration at which no visible growth was noted as MBC (Soussy et al., 2010; Adeshina et al., 2012).

\section{Statistical analysis}

All the data were analyzed by one-way ANOVA and differences between the means were assessed with Dunnet/Turkey's multiple comparison tests using Graph Pad software, version 5.01 (USA). Differences were considered significant at $\mathrm{p}<0.05$.

\section{Results and Discussion}

Results of colonies counting from doseresponse of soap "MORINDA" and control soap on in vitro growth of $S$. aureus and $P$. aeruginosa are recorded respectively in Tables 1 and 2. These data made it possible to determine antibacterial parameters of soaps against $S$. aureus (Table 3 ) and $P$. aeruginosa (Table 4). The results showed significantly (p $<0.05)$ high bactericidal activity of soap

"MORINDA" against two strains tested with same values of MIC and MBC of 31.25 $\mathrm{mg} / \mathrm{mL}$. Control soap presented the lower bactericidal effect with MIC of $62.50 \mathrm{mg} / \mathrm{mL}$ for the two strains tested and MBC of 125.00 $\mathrm{mg} / \mathrm{mL}$ and $62.50 \mathrm{mg} / \mathrm{mL}$ respectively for $S$. aureus and $P$. aeruginosa. According to $\mathrm{MBC}$ values, soap "MORINDA" is 4 times more effective than control soap against $S$. aureus and 2 times with $P$. aeruginosa.

Comparatively to control soap, hexane extract of M. morindoides gave to soap "MORINDA" effectiveness bactericidal power against the two bacteria tested. This interesting bactericidal activity of soap "MORINDA" corroborate our previous investigations which showed antifungal activity of this soap (Toure et al., 2010) and high antibacterial activity of hexane extract of $M$. morindoides (Ouattara $e t$ al., 2013). In fact hexane extract of $M$. morindoides incorporated to $10 \%$ as active agent in formulation of anti-infectious soap expresses its antimicrobial properties. 
Table.1 Results of colony counting from dose-response of soaps on in vitro growth of Staphylococcus aureus

\begin{tabular}{ccc} 
Soaps concentrations $(\mathrm{mg} / \mathrm{mL})$ & Control soap & Soap "MORINDA" \\
\hline 0.00 & $100 \pm 1.2$ & $100 \pm 0.14$ \\
3.90 & $42 \pm 0.6$ & $26 \pm 1.2$ \\
7.81 & $22 \pm 0.4^{* *}$ & $17 \pm 1.4^{* *}$ \\
15.62 & $9 \pm 0.4$ & $5 \pm 0.2$ \\
31.25 & $4 \pm 0.6^{* *}$ & $0 \pm 0.00$ \\
62.50 & $0 \pm 0.00$ & $0 \pm 0.00$ \\
125.00 & $0 \pm 0.00$ & $0 \pm 0.00$ \\
\hline
\end{tabular}

Values are the mean $\pm \operatorname{SEM}(n=3)$.

** Mean values with the same superscript within a row do not differ significantly $(\mathrm{p}<0.05)$.

Table.2 Results of colony counting from the dose-response of soaps on the in vitro growth of $P$. aeruginosa

\begin{tabular}{ccc} 
Soaps concentrations $(\mathrm{mg} / \mathrm{mL})$ & Control soap & Soap "MORINDA" \\
\hline 0.00 & $100 \pm 1.4$ & $100 \pm 1.14$ \\
3.90 & $38 \pm 1.2$ & $19 \pm 0.22$ \\
7.81 & $17 \pm 0.6^{* *}$ & $8 \pm 0.6^{* *}$ \\
15.62 & $6 \pm 0.8$ & $2 \pm 0.12$ \\
31.25 & $3 \pm 0.4$ & $0 \pm 0.00$ \\
62.50 & $0 \pm 0.00$ & $0 \pm 0.00$ \\
125.00 & $0 \pm 0.00$ & $0 \pm 0.00$ \\
\hline
\end{tabular}

Values are the mean $\pm \operatorname{SEM}(\mathrm{n}=3)$.

** Mean values with the same superscript within a row do not differ significantly $(\mathrm{p}<0.05)$.

Table.3 Antibacterial parameters $(\mathrm{mg} / \mathrm{mL})$ of soaps against Staphylococcus aureus

\begin{tabular}{lccccc} 
Soaps & $\mathrm{IC}_{50}$ & $\mathrm{MIC}$ & $\mathrm{MBC}$ & $\mathrm{MBC} / \mathrm{MIC}$ & Interpretation \\
\hline Control soap & $3.36 \pm 1.36$ & 62.50 & 125.00 & 2 & Bactericidal \\
Soap "MORINDA" & $2.64 \pm 0.86$ & 31.25 & 62.50 & 1 & Bactericidal \\
\hline
\end{tabular}

Mean \pm SEM, $\mathrm{n}=3, \mathrm{p}<0.05$

Table.4 Antibacterial parameters (mg/mL) of soaps against Pseudomonas aeruginosa

\begin{tabular}{lccccc} 
Soaps & $\mathrm{IC}_{50}$ & MIC & MBC & MBC/MIC & Interpretation \\
\hline Control soap & $3.15 \pm 1.14$ & 62.50 & 62.50 & 1 & Bactericidal \\
Soap "MORINDA" & $2.41 \pm 0.57$ & 31.25 & 62.50 & 1 & Bactericidal \\
\hline
\end{tabular}

Mean \pm SEM, $\mathrm{n}=3, \mathrm{p}<0.05$ 
In addition similar work on Aloe vera and Ageratum conyzoides (Moody et al., 2004), Tithonia diversifolia, Aloe secundiflora and Azadirachta indica (Kareru et al., 2010) and Senna alata (Oladele et al., 2010) has also shown that these extract express their antimicrobial virtue when they used as active compound in anti-infectious soaps. The results of this study provide a basis for prevention and effective treatment of microbial cutaneous infections. In perspectives we plan to evaluate toxicity of soap "MORINDA" and carry out clinical tests for treatment of cutaneous infections.

\section{References}

Abdel Rahman, S., Abd-Ellatif, S., Deraz, S. and Khalil, A. 2011. Antibacterial activity of some wild medicinal plants collected from western Mediterranean coast, Egypt: Natural alternatives for infectious disease treatment. African $J$. Biotechnol., Vol. 10(52), 10733-10743.

Abiramasundari, P., Priya, V., Jeyanthi, G.P., and Gayathri Devi, S. 2011. Evaluation of the Antibacterial activity of Cocculus hirsutus. Hygeia: J. Drugs and Med., Vol. 3 (2), 26-31.

Adeshina, G.O., Kunle, O.F., Onaolapo, J.A., Ehinmidu, J.O. and Odama, L.E. 2012. Phytochemical and antibacterial studies of hexane extract of Alchornea cordifolia Leaf, Phytochemicals as nutraceuticals global approaches to their role in nutrition and health, $\mathrm{Dr}$ Venketeswer Rao (Ed.), ISBN : 978953-51-0203-8, 278p.

Bagre, I., Bahi, C., Gnahoue, Djaman, A.J. and Guede-Guina, F. 2007. Phytochemical composition and evaluation of in vitro antifungal activity of leaves of Morinda morindoides (Baker) Milne-redh (Rubiaceae) against Aspergillus fumigatus and Candida albicans. J. des Sci. Pharmaceutiques et Biologiques, 8: 15-23.

Caubergs, L. 2008. La fabrication du savon : aspects techniques, économiques et sociaux. (C) ATOL, Leuvens estraat 5/1, 3010 Leuven, Belgique 97p.

Cimanga, K., De Bruyne, T., Lasure, A., Li, Q., Pieters, L., Claeys, M., Vanden Berghe, D., Kambu, K., Tona, L. and Vlietinck, A.J. 1995. Flavonoid oglycosides from the leaves of Morinda morindoides. Phytochem., 38: 13011303.

Cimanga, K., Kambu, K., Tona, L., Hermans, N., Apers, S., Totté, J., Pieters, L. and Vlietinck, A.J. 2006. Cytotoxicity and in vitro susceptibility of Entamoeba histolytica to Morinda morindoides leaf extracts and its isolated constituents. $J$. Ethnopharmacol., 107: 83-90.

Kambu, K., Tona, L., Luki, N., Cimanga, K. and Uvoya, A. 1990. Antibacterial activity of extracts from plants used in preparations as antidiarrheal at Kinshasa, Zaire. Annales Pharmaceutiques Françaises, 48(5): 255-263.

Kareru, P.G., Keriko, J.M., Kenji, G.M., Thiong'o, G.T., Gachanja, A.N. and Mukiira, H.N. 2010. Antimicrobial activities of skincare preparations from plants extracts. African J. Traditional Complementary Alternative Med., 7(3): 214-218.

Langlois-Klassen, D., W. Kipp, G. Jhangri and T. Rubaale. 2007. Use of traditional herbal medicine by AIDS patients in Kabarole District, Western Uganda. American J. Trop. Med. Hygiene, 77: 757-763.

Meite, S., N'guessan, J.D., Bahi, C., Yapi, H.F., Djaman, A.J. and Guede-Guina, F. 2009. Antidiarrheoal activity of the ethyl acetate extract of Morinda morindoides in rats. Trop. J. Pharmaceutical Res., 8: 201-207.

Moody, J.O., Adebiyi, O.A. \& Adeniyi, B.A., 
2004. Do Aloe vera and Ageratum conyzoides enhance the antimicrobial activity of traditional medicinal soft soaps (osedudu)? J. Ethnopharmacol., 92(1): 57- 60.

Moroh, J.L.A., Bahi, C., Dje, K., Loukou, Y.G. and Guede-Guina, F. 2008. Study of the antibacterial activity of Morinda morindoides (Baker) Milne- Readhead (Rubiaceae) acetatique extract (ACE) on in vitro growth of Escherichia coli strains. Bulletin de la Société Royale des Sciences de Liege, 77: 44-61.

Oladele, A.T., Dairo, B.A., Elujoba, A.A. and Oyelami, A.O. 2010. Management of superficial fungal infections with Senna alata ("alata") soap: preliminary report. African J. Pharmacy and Pharmacol., 4(3): 098-103.

Ouattara, K., Doumbia, I., Touré, A., Djaman, A.J. et Coulibaly, A. 2013. Activité antibactérienne des extraits des feuilles de Morinda morindoides (Morinda, Rubiaceae) sur Staphylococcus aureus et Pseudomonas aeruginosa. Phytothérapie, 11:172-177.

Parrales, R.S., Cruz, B.V., Cobos, D.S., Lang, A.L.A., Jimenez-Estrada, M. and Martinez, M. 2012. Anti-inflammatory, analgesic and antioxydant properties of Bursera morelensis bark from San Rafael, Coxcatlan, Puebla (Mexico): Implications for cutaneous wound healing. J. Med. Plant Res., 6(44): 5609-5615.

Patwardhan, B., D. Warude, P. Pushpangadan and B.N. Narendra. 2005. Ayurveda and traditional chinese medicine: A comparative overview. Evidence-Based Complementary Alternative Med., 2: $465-473$.

Soussy, C.J., Cavallo, J.D., Chardon, H. 2010. Comité de l'antibiogramme de la Société française de microbiologie. Édition de janvier, $50 \mathrm{p}$.

Toure, A., Bahi, C., Bagre, I., N'guessan, J.D., Djaman, A.J. and Coulibaly, A. 2010. In vitro antifungal activity of soap formulation of the hexane leaf extract of Morinda morindoides (Morinda; Rubiaceae). Trop. J. Pharmceutical Res., 9: 237-241.

Zirihi, G.N., Mambu, L., Guédé-Guédé, F., Bodo, B. and Grellier, P. 2005. In vitro antiplasmodial activity and cytotoxicity of 33 West African plants used for the treatment of malaria. $J$. Ethnopharmacol., 98: 281-285.

\section{How to cite this article:}

Toure Abdoulaye, Konan Kouakou Severin, Coulibaly Bakary, Ouattara Karamoko and Coulibaly Adama. 2017. Antibacterial Activity of Soap containing Hexane Extract of Leaves of Morinda morindoides (Morinda; Rubiaceae) against Staphylococcus aureus and Pseudomonas aeruginosa. Int.J.Curr.Microbiol.App.Sci. 6(1): 512-517. doi: http://dx.doi.org/10.20546/ijcmas.2017.601.061 